\title{
Yield and quality of 'Italia' grapes submitted to irrigation and fertilization control at the San Francisco Valley, Brazil
}

\author{
Victor Pimenta Martins de Andrade ${ }^{*}$, Merideise da Silva Dias²; José Aliçandro Bezerra da Silva', \\ José Sebastião Costa de Sousa ${ }^{2}$, Welson Lima Simões ${ }^{3}$ \\ 'Federal University of the São Francisco Valley, Juazeiro, BA, Brazil \\ ${ }^{2} F e d e r a l$ Institute of Science and Technology, Sertão Pernambucano, Petrolina, PE, Brazil \\ ${ }^{3}$ Empresa Brasileira de Pesquisa Agropecuária Semi-arid, Petrolina, PE, Brazil \\ Corresponding author, e-mail: victor.pimenta@ifsertao-pe.edu.br
}

\begin{abstract}
The aim of this research was to evaluate aspects related to flowering, fruiting and quality of 'Italia' grape produced under different irrigation and fertilization. The experiment was performed from October, 2014 to February, 2015, in a production area of 0.50 ha at IFSERTÃO-PE, in Petrolina-PE, Brazil. The experiment was carried out in a randomized blocks design, with a split block scheme, with four irrigation treatments (plots), four fertilizer treatments (subplots) and four repetitions. The plots consisted of the multiplying factors, 0.75 (L) ; 1.00 (L2); 1.25 (L3) and 1.50 (L4), of the recommended crop coefficients $(\mathrm{KC})$ by Embrapa Semi-Arid for the 'Italia' grapevine. The subplots were composed by the factors 1.00 (AD1), 0.75 (AD2), 0.50 (AD3) and 0.25 (AD4) of the recommended fertilization with an BIOSON as organic product (commercial name). It was observed that the reduction in water depth provided greater number of buds per branch and a larger number of clusters per plant. The highest yields were obtained with lower irrigation depths and $50 \%$ and $65 \%$ of the recommended fertilization. The highest soluble solids of the fruit were achieved using the $75 \%$ of irrigation $\mathrm{Kc}$ and $25 \%$ of recommended mineral fertilization. The lower total acidity values were obtained with the Kc multiplication factors that were lower than 1.04 and higher than 1.22 .
\end{abstract}

Keywords: Crop coefficient, soluble solids, total acidity

\section{Produção e qualidade da uva 'Itália' submetida a controle de irrigação e adubação no vale do Submédio São Francisco}

\section{Resumo}

O objeto desta pesquisa foi avaliar aspectos referentes à floração, frutificação e a qualidade da uva 'Itália' produzida sob diferentes irrigações e adubações. O experimento foi realizado de outubro de 2014 a fevereiro de 2015, em 0,50 ha de uma área de produção do Campus Petrolina Zona Rural do IFSERTÃO-PE, em Petrolina-PE. O delineamento estatístico foi o de blocos casualizados, em esquema de faixas, com quatro tratamentos de irrigação (parcelas), quatro tratamentos de adubação (subparcelas) e quatro repetições. As parcelas foram constituídas dos fatores de multiplicação, 0,75 (L1); 1,00 (L2); 1,25 (L3) e 1,50 (L4), dos coeficientes de cultura (KC) recomendados pela Embrapa Semiárido para a videira 'Itália'. As subparcelas foram constituídas pelos fatores 1,00 (AD1) , 0,75 (AD2) , 0,50 (AD3) e 0,25 (AD4) da adubação recomendada, acrescidas do produto orgânico BIOSON (nome comercial). Observou-se que a redução na lâmina de irrigação proporcionou maior número de gemas por ramo e maior número de cachos por planta. As maiores produtividades foram conseguidas com as menores lâminas de irrigação e adubação entre 50 e $65 \%$ da recomendação. Os maiores teores de sólidos solúveis foram alcançados para irrigações com $75 \%$ do Kc recomendado e $25 \%$ da adubação mineral. Os menores valores de acidez total foram obtidos com os fatores de multiplicação do Kc menores que 1,04 e maiores que 1,22.

Palavras chave: acidez total, coeficiente de cultura, sólidos solúveis 


\section{Introduction}

In São Francisco Valley, Brazil, the grape production has shown great expansion, due to factors such as light, temperature and water availability which favors the production of this crop throughout the year (Albuquerque et al., 2013). Thus, the conditions in the region allow five production cycles in 2 years. However, to balance the production with market gaps, the region is producing two cycles per year, in the first and second half (Pommer, 2006). Among the various table grape varieties produced in the region, Souza et al. (2011) highlight that the cultivar 'Italia' is the largest in exported volume. However, high productivity variation has been observed in this cultivar due to the crop management.

Some of the main limiting factors of agricultural production in the Northeast of Brazil, specifically in the semiarid region, are the scarce and irregular rainfall (Soares et al., 2013) and the soil fertility.

Water stress is one of the biggest growth and productivity impediments of plants and progressively reduces the photosynthetic capacity. Under these conditions, the plants cannot use all light energy for producing ATP and NADPH2 (Oukarroum et al., 2007). On the other hand, the water excess reduces the oxygen concentration and hinders the root respiration, promoting intense soil leaching (Aurora et al., $2011)$.

Santos \& Kaye (2009) also assert that under no restrictive levels of water in the soil, the vegetative growth is excessive and competes with berries for assimilates. But a very severe drought can adversely affect the productivity and grape quality (Busato et al., 2011).

Despite several scientific papers about the management of the "Italia" vine irrigation (Avila Netto et al., 2000; Soares \& Costa, 2000), there are still doubts about the crop water demand, when the use of different irrigation plates is a very practical way to estimate the species water needs (Azevedo \& Bezerra, 2008).

Regarding soil fertility, the use of organic acids in the São Francisco Valley, especially humic acids, has raised the growers interest (Cunha et al., 2009). An organic and incipient product in the market, based on humic and fulvic acids, called BIOSON, has been used by many grape growers in the region, without, however, scientific evidence of their effectiveness when associated with mineral fertilization. It is known, however, that humic substances act as biostimulants and soil conditioners, improving their chemical, physical and microbiological properties, such as water and nutrients holding capacity, the aggregation of particles and the porosity (Baldotto et al. 2007).

Thus, the aim of this research was to evaluate the production and quality of 'Italia' grapes under different irrigation and mineral fertilization, using the BIOSON product.

\section{Material e Methods}

The experiment was performed from October, 2014 to February, 2015, in a 'Italia' grape production area with 0.50 ha of the IFSERTÃO-PE Campus Petrolina Zona Rural, in the municipality of Petrolina, Pe, Brazil, at 920 'South, $40^{\circ} 41^{\prime}$ ' West and average altitude of $418 \mathrm{~m}$.

The climate according to Koppen classification is BSwh '(Azevedo et al., 2003) and the soil of the area was classified as a yellow oxysol. The vineyard was conducted in trellis system with spacing of $3.50 \times 2.50 \mathrm{~m}$, under micro sprinkler irrigation system with emitters spaced at $3.50 \times 5,00 \mathrm{~m}$ (one emitter for two plants).

The experiment was performed in a randomized block design with a split block scheme, with four irrigation treatments (plots), four fertilization levels (subplots) and four repetitions. The irrigation treatments consisted of multiplying factors of the crop coefficients (KC) $(0.75,1.00,1.25$ and 1.50 , respectively called L1, L2, L3 and L4), as suggested by Soares \& Costa (2000), Table 1. The subplots were defined as mineral fertilizations according to amounts recommended by the Pernambuco State fertilization Manual (Cavalcanti et al., 2008); and the factors 1.00; $0.75 ; 0.50$ and 0.25 of the recommended fertilization with BIOSON as organic product were used and the treatments were: AD1, AD2, AD3 and AD4, respectively.

The volume of BIOSON added to the fertilization was $20 \%$ of the conventional fertilization recommendation (ie, $20 \mathrm{~L}$ of product per $100 \mathrm{~kg}$ of fertilizer - this is the proportion used 
by growers in the region and recommended by the product company). The material was diluted in a fertilizer tank and applied with watering cans.

Table 1. Average values of crop coefficient $(\mathrm{kc})$ for 'Italia' grapevines grown in Petrolina-PE, Brazil and number of days corresponding to each phenological stage after pruning (DAP) (Soares \& Costa, 2000).

\begin{tabular}{lcc}
\hline Phenological stage & DAP & kC \\
\hline Period of budding & 0 to 8 & 0.59 \\
Vegetative growth & 9 to 28 & 0.60 \\
Pre and full-bloom & 29 to 40 & 0.69 \\
1st stage of fruit growth & 41 to 55 & 1.11 \\
Fruit growth arrest & 56 to 80 & 0.90 \\
2nd stage of fruit growth & 81 to 110 & 1.12 \\
Fruit final maturation & 111 to 130 & 1.00 to 0.60 \\
Phenological pause & 131 to 160 & 0.75 \\
\hline
\end{tabular}

The crop treatments were performed in the same way as in previous years leaving, at the pruning production, 20 branches in each plant, with a length of $50 \mathrm{~cm}$ (enough for tying the branches on the second wire of the trellis).

To analyze the effects of different water amounts through irrigation associated to different fertilizations, parameters related to plant floral formation were evaluated (number of buds per branch and number of clusters per plant). It was also evaluated variables related to productivity (total mass and clusters circumference) and fruit quality.

To measure the number of buds per branch, six branches per plant from the central portion of the vine were sampled, three on each side.

For the circumference analysis, there were representatively selected 10 clusters in each plant. The measurement occurred in the final phase of the cycle, at 113 days after the production pruning (DAPP).

After harvesting, the estimated yield was calculated considering the production of each plant and the used spacing.

For soluble solids and total acidity analysis, 25 berries from each useful plant were taken in different clusters and positions (top, middle and bottom of each cluster), so that the position of clusters and the berries in each cluster would not influence the content of transported assimilated. The berries were macerated and from the extracted flesh was analyzed the soluble solids content with the aid of a manual refractometer. The total acidity was determined from titration with $0.1 \mathrm{~N} \mathrm{NaOH}$ solution and phenolphthalein solution as indicator (IAL, 2008). For data statistical analysis, the software SISVAR (Ferreira, 2011) was used.

\section{Results and Discussion}

For the variable number of buds a significant interaction between the treatments of irrigation and fertilization was observed (Figures $1 \mathrm{~A}$ and $1 \mathrm{~B})$. With an increase on the water depth, a reduction in the number of buds per branch (Figure 1B) was noted, which showed higher internodal growth and more vigor in the branches of vines submitted to the most abundant irrigations. This result is in accordance to Botelho et al. (2006) that affirmed that the vigor of the vine branches reduces the fertility of the buds, reducing their productivity. The vine presents a peculiarity on its physiological mechanisms, which direct the photoassimilates for vegetative or reproductive growth, according to the plant demand (Keller et al., 2008).

According to the values found, the minimum estimated number of buds per branch was observed for the treatment L4 (5.55 buds per branch), which corresponded to $63.39 \%$ of the mineral fertilization recommended added of the tested product (AMPT) (Figure 1A), reaching the nullity of buds per branch for the Kc multiplication factor from 3.07 (Figure 1B).

For the variable number of clusters, the treatment L1 resulted in a higher mean when compared to other treatments (Figure 2A), being possible to assume that the irrigation was 
excessive for the L2, L3 and L4 treatments. The reduction of irrigation depth applied in pre and full bloom stages provided the greatest flowering in quantitative terms, resulting in a higher number of clusters.
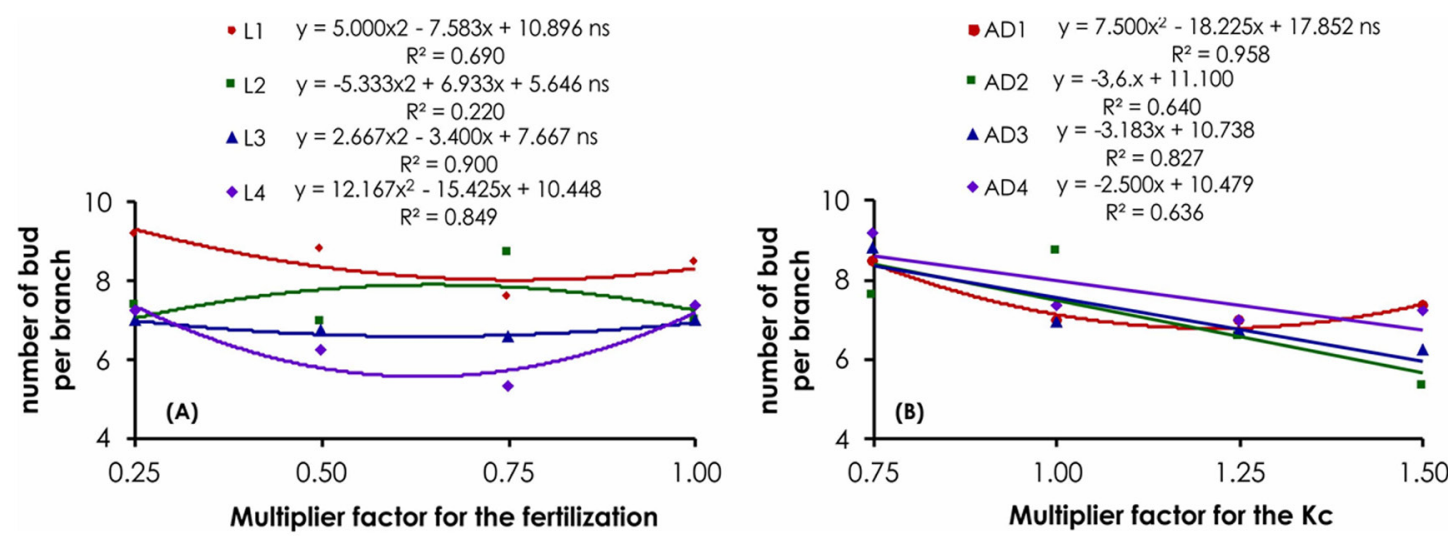

Figure 1. Number of buds (buds) per branch according to different fertilization (A) and irrigation (B) treatments.
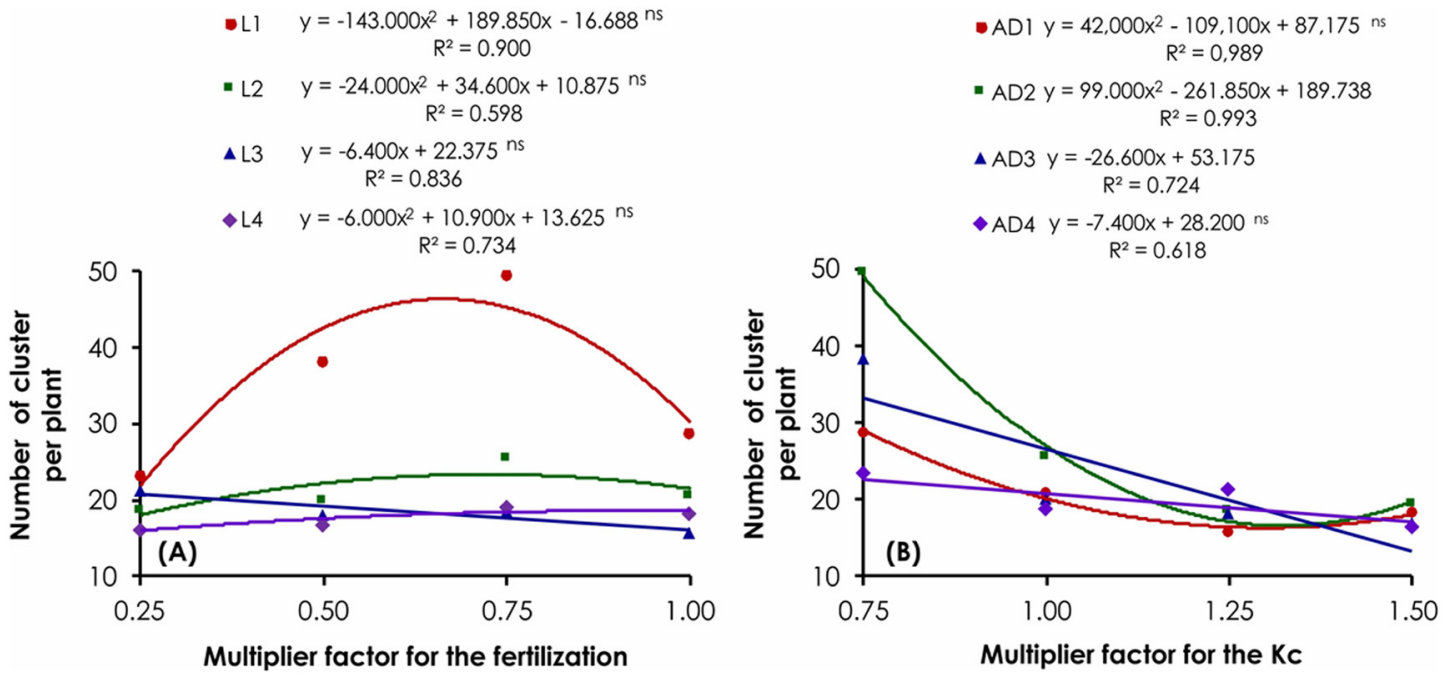

Figure 2. Number of clusters per plant according to different fertilization (A) and irrigation (B) treatments.

The excess of the vigor of the vines branches was probably a limited factor for the ability of the buds to produce flowers and then fruits. However, Souza et al. (2013) reported no difference in the number of clusters on the 'Superior Seedless' vines submitted to soil tensions of $0,-30,-50$ and $-70 \mathrm{kPa}$.

Despite nutrients are essential for the growth and development cycles of vine plants, such as nitrogen, which is considered an important element involved in the inflorescence formation and fruit production (Mullins et al., 2000). Rock ef al. (2015) evaluating three production cycles of the 'Syrah' vine submitted to increasing levels of nitrogen fertilization, found no difference in the number of clusters. This information can lead to a conclusion that the rational reduction of the mineral fertilization, or depending on the nutrient content in the soil or the aggregation of an organic product, as tested in this research, does not generate reduction in the number of clusters produced by the vine.

For the yield variables, significant effect was observed only for regressions of the fertilizations interactions on the treatments $\mathrm{L} 2$ and L1 (Figure $3 \mathrm{~A}$ and $3 \mathrm{~B}$, respectively) and for irrigations on the treatments $A D 1, A D 2$ and AD3 (Figures 3C, 3D and 3E, respectively).

The higher yield (15.78 t.ha $\left.^{-1}\right)$ was achieved with the treatment $L 1$ (75\% of the Kc that lead to Kc values between 0.44, for the budding period and 0.84 for the second phase of the fruit growth, Table 1) and $65 \%$ of the conventional fertilization (Figure 3B). For the irrigation of $100 \%$ 
of the Kc (Same Kc values of the table 1), the maximum yield would be $9.77 \mathrm{t} / \mathrm{ha}^{-1}$ with $71 \%$ of the conventional fertilization (Figure $3 \mathrm{~A}$ ). These observations are close to the recommended by Ávila Netto et al. (2000), that indicate for the 'Italia' grapevines at the São Francisco Valley, Brazil, values of $\mathrm{Kc}$ between 0.50 (maturation) and 0.74 (berries formation). For other varieties, such as 'Crimson Seedless', Ferreyra et al. (2006) did not observed difference on yield using 50 and $100 \%$ of the ETc on the irrigation management.

Regarding the fertilization, the AD3 treatments $150 \%$ of the conventional mineral fertilization - factor 0.50, Figure $1 \mathrm{E}$ ) resulted in the highest yield (15.71 t.ha $\left.\mathrm{H}^{-1}\right)$ with irrigations of $75 \%$ of the $\mathrm{Kc}$, and the minimum yield would be 3.89 t.ha- ${ }^{-1}$ for irrigations with $142 \%$ of the $\mathrm{Kc}$, yield that would be achieved with $139 \%$ and $165 \%$ of the
KC for the treatments $A D 1$ and AD2 (Figure 3C and 3D, respectively). This can indicate that the organic product used increased the efficiency of the mineral fertilization, reducing the need of the product application, achieving an optimum range between 50 and $65 \%$ of the recommended mineral fertilization for the 'Italia' grapevine.

Regarding the grape quality, for the soluble solids contents, a significant effect of the fertilization was observed only for the treatment LI and the for the irrigations on the treatment AD4, with minimum values of 14.06 and $15.00{ }^{\circ}$ Brix for the treatment $\mathrm{L} 1$ with $67.82 \%$ of the conventional fertilization (Figure 2B) and for the AD4 treatment with $1.18 \%$ of the Kc (Figure 2A), respectively. The maximum values were achieved, significantly, with the treatments L1 and AD4 (15.22 Brix) and L4 with AD4 (15.67 Brix).
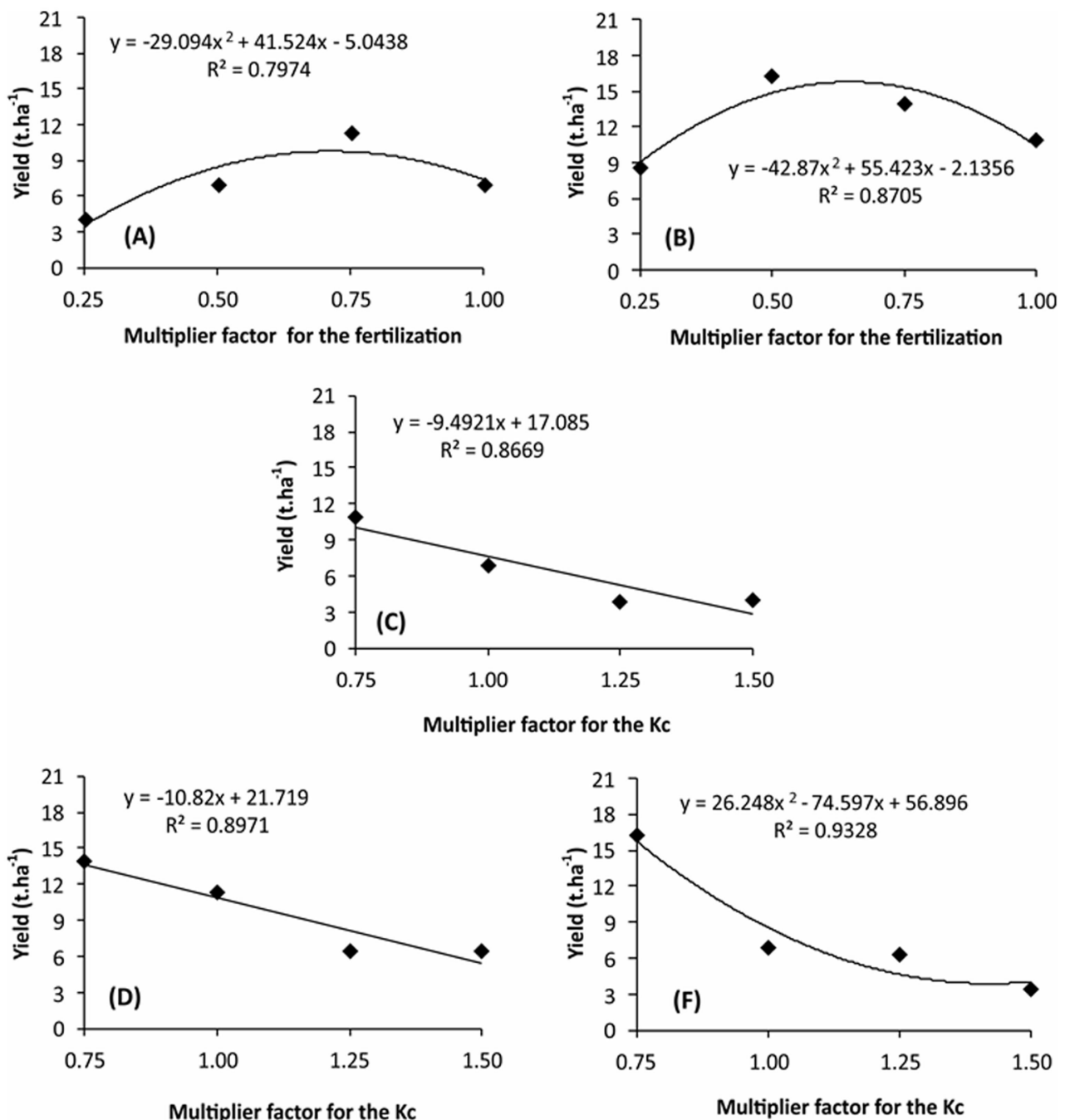

Figure 3. Yield of 'Italia' grapes in Petrolina/PE, Brazil, according to different fertilizations in the irrigation treatments with: (A) $100 \%$ and (B) $75 \%$ of the recommended Kc by Soares \& Costa (2000); and different irrigation depths on the fertilization treatments with: (C) 100, (D) 75 and (E) $50 \%$ of the conventional mineral fertilization with an addition of organic product. 

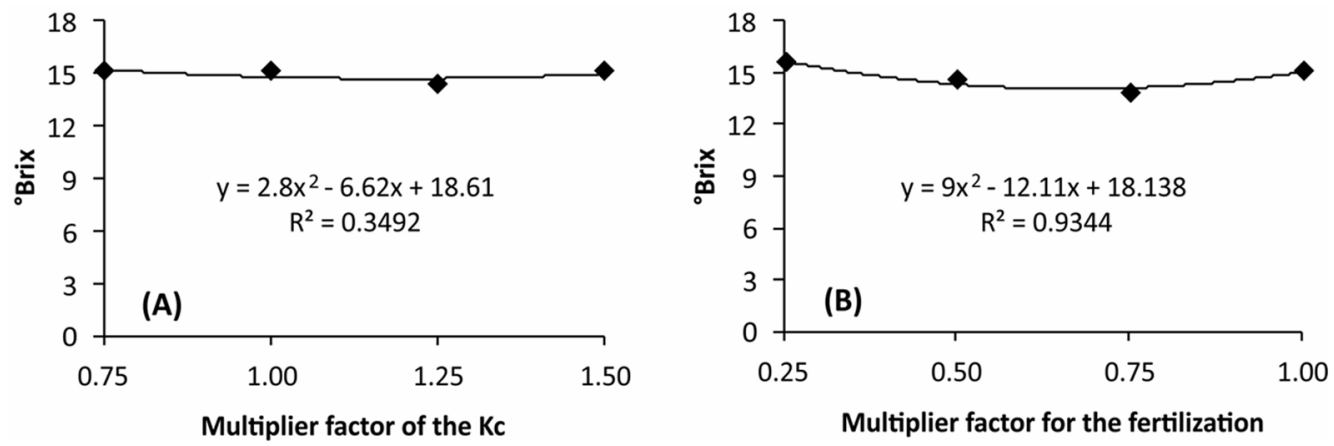

Figure 4. Soluble solids content (SS) for the grape "Italia" in Petrolina, PE, Brazil, for different irrigation depths and $25 \%$ of the conventional mineral fertilization adding an organic product (A); and different fertilizations for the irrigation with $75 \%$ of the recommended Kc by Soares \& Costa (2000) (B).

According to the irrigation treatments, an increase on the soluble solids content was observed, with and increase or decrease of the irrigation depths. According to Bassoi et al. (2011) and Busato et al. (2011), the imposition of a moderate water deficit for the vine crop implies in an increase of the grape soluble solids content. The lower number of clusters of the L4 treatment may have favored an increase of the soluble solids content, when comparing to the L2 and L3 treatment.

For the variable total acidity of the grapes, was observed a significant effect of the fertilization only for the treatment L1 (Figure 5A) and of the irrigations for all fertilization treatments (Figures 5B, 5C, 5D and 5E). For the treatment LI, the estimation of the maximum acidity value is $8.81 \mathrm{~g} . \mathrm{L}^{-1}$ of tartaric acid with the use of $69 \%$ of the recommended mineral fertilization added of the BIOSON product. For the treatments AD1, AD2, $A D 3$ and $A D 4$, the estimation for the maximum acidity values were $9.25,9.84,9.31$ and 9.34 g.. $\mathrm{L}^{-1}$ of tartaric acid, with $\mathrm{Kc}$ factor of 1.22, 1.04, 1.14 and 1.13 , respectively.

The lower total acidity values were observed for the treatments $L 1$ and $L 4$, confirming the results observed by Busato et al. (2011), with lower acidity for 'Niagara Rosada' vines under water deficit ( 0 and $33 \%$ of the irrigation depth replacement). Marinho et al. (2009) and Shellie (2006) also concluded that the irrigation deficit lead to a reduction on grape total acidity in studies with the cultivars 'Superior Seedless' and 'Merlot', respectively.

According to Jackson \& Lombard (1993), an excessive irrigation increases the vigor of the branches and its competition for photoassimilates with the fruits, compromising the phenolic compounds synthesis, which can explain the reduction on acidity contents of the treatment $L 4$. Thus, it is estimated that the lowest values for acidity are achieved with Kc's lower than 1.04 and higher than 1.22 .

\section{Conclusions}

The reduction on the irrigation lead to a higher number of buds per branches and, consequently, a higher number of clusters.

Higher yield for 'Itália' grapes were achieved with the lowest irrigation depths and fertilization between 50 and $65 \%$ of the conventional recommendation.

The higher soluble solids contents were achieved for irrigations with $75 \%$ of the crop coefficient recommended by Soares \& Costa (2000) and $25 \%$ of the mineral conventional fertilization with the addition of organic products.

The lower values for the fruit total acidity were obtained with the Kc factors lower than 1.04 and higher than 1.22 . 

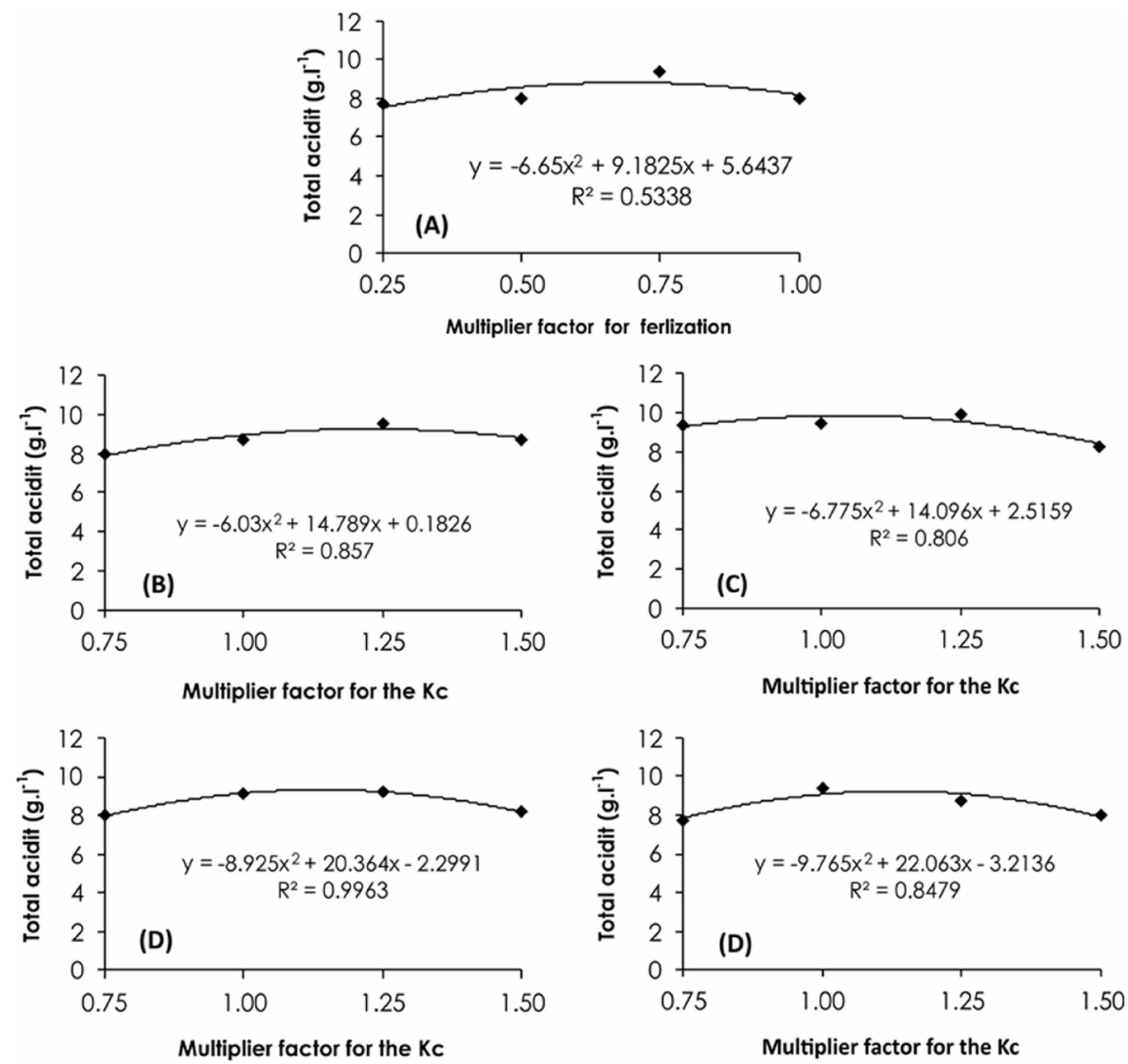

Figure 5. Total acidity of 'Itália' vine in Petrolina, PE, Brazil (g. $\mathrm{L}^{-1}$ of tartaric acid) for different fertilization with $75 \%$ of the recommended Kc by Soares \& Costa (2000) (A); and different irrigation depths for the AD1 (B), AD2 (C), AD3 (D) and AD4 (E) fertilization treatments.

\section{References}

Albuquerque, A.H.P., Viana, T.V.A., Marinho, A.B. Sousa, G.G., Azevedo, B.M. 2013. Irrigação e fertirrigação potássica na cultura da videira em condições semiáridas. Pesquisa Agropecuária Tropical 43: 315-321.

Aurora, V.K., Singh, C.B., Sidhu, A.S., Thind, S.S. 2011 . Irrigation, tillage and mulching effects on soybean yield and water productivity in relation to soil texture. Agricultural Water Management 98: 563-568.

Avila Netto, J., Azevedo, P.V., Silva, B.B., Soares, J.M., Teixeira, A.H.C. 2000. Exigências hídricas da videira na região do Submédio São Francisco. Pesquisa Agropecuária Brasileira 35: 1559-1566.

Azevedo, J.H.O., Bezerra, F.M.L. 2008. Resposta de dois cultivares de bananeira a diferentes lâminas de irrigação. Revista Ciência Agronômica 39: 2833.

Azevedo, P.V., Silva, B.B., Silva, V.P.R. 2003. Walter requirements of irrigated mango orchards in
Northeast Brazil. Agricultural Water Management 58: 241-245.

Baldotto, M.A., Canellas, L.P., Canela, M.C., Simões, M.L., Martin-Neto, L., Fontes, M.P.F., Velloso, A.C.X. 2007. Propriedades redox e grupos funcionais de ácidos húmicos isolados de adubos orgânicos. Revista Brasileira de Ciência do Solo, 3: 465-475.

Bassoi, L.H., Gonçalves, S.O., Santos, A.R. L., Silva, J.A., Lima, A.C.M. 2011 . Influência de manejos de irrigação sobre aspectos de ecofisiologia e de produção da videira cv. Syrah/Paulsen 1103. Revista Irriga 16: 395-402.

Botelho, R.V., Pires, E.J.P., Terra, M.M. 2006. Fertilidade de gemas em videiras: fisiologia e fatores envolvidos. Revista Ambiência 2: 129-144.

Busato, C.C.M., Soares, A.A., Sediyama, G.C., Motoike, S.Y., Reis, E.F. 2011. Manejo da irrigação e fertirrigação com nitrogênio sobre as características químicas da videira 'Niágara Rosada'. Revista Ciência Rural 41: $1183-1188$. 
Cavalcanti, F.J. A. 2008. Recomendações de adubação para o Estado de Pernambuco: $2^{a}$ aproximação. 3 ed. IPA, Recife, Brasil. 212p.

Cunha, T. J. F, Bassoi, L. H., Simões, M. L., MartinNeto, L., Petrere, V. G., Ribeiro, P. R. A. 2009. Ácidos húmicos em solo fertirrigado no Vale do São Francisco. Revista Brasileira de Ciência do Solo 33: 1583-1592.

Ferreira, D.F. 2011 . Sisvar: a computer statistical analysis system. Ciência e Agrotecnologia 35: 1039-1042

Ferreyra, R., Selles, G., Silva, H., Ahumada, R., Muñoz, I., Muñoz, V. 2006. Efecto del agua aplicada en las relaciones hídricas y productividad de la vid 'Crimson Seedless'. Pesquisa Agropecuária Brasileira 41: 1109-1118.

IAL - Instituto Adolfo Lutz. 2008. Métodos químicos e físicos para análise de alimentos. 4 Ed. Normas analíticas do Instituto Adolfo Lutz, São Paulo, Brasil. 1020p.

Jackson, D.I., Lombard, P.B. 1993. Environmental and management practices affecting grape composition and wine quality - a review. American Journal Enology and Viticulture 44: 409-430.

Keller, M., Smithyman, R.P., Mills, L.J. 2008. Interactive effects of deficit irrigation and crop load on cabernet sauvignon in an arid climate. American Journal of Enology and Viticulture 59: 221-234.

Marinho, L. B., Rodrigues, J. J. V, Soares, J.M., Lima, M.A.C., Moura, M.S.B., Brandão, E.O, Silva, T.G.F. Calgaro, M. 2009. Produção e qualidade da videira 'Superior Seedless' sob restrição hídrica na fase de maturação. Pesquisa Agropecuária Brasileira 44: 1682-1691.

Mullins, M.G., Bouquet, A., Williams, L.E. 2000. Biology of the grapevine. Cambridge University Press, Cambridge, UK. 239 p.

Oukarroum, A. Madidi, S. E.. Schansker, G., Strasser, R. J. 2007. Probing the responses of barley cultivars (Hordeum vulgare L.) by chlorophyll a fluorescence OLKJIP under drought stress and re-watering. Environmental and Experimental Botany 60: 438-446,

Pommer, C.V. Double Cropping of Table Grapes in Brazil. 2006. Chronica Horticulturae 45: 22-25.

Rocha, M.G., Bassoi, L.H., Silva, D.V. 2015. Atributos do solo, produção da videira 'Syrah' irrigada e composição do mosto em função da adubação orgânica e nitrogenada. Revista Brasileira de Fruticultura 37: 220-229.

Santos, A.O., Kaye, O. 2009. Composição quali- quantitativa da produção de 'Syrah' cultivada sob estresse hídrico transiente. Revista Brasileira de Engenharia Agrícola e Ambiental 13: 272-281.

Shellie, K.C. 2006. Vine and berry response of Merlot (Vitis vinifera L.) to differential water stress. American Journal of Enology and Viticulture 57: 514-518.

Soares, C.A., Júnior, A.F.R., Silva, N.S., Mousinho, F.E.P., Zanini, J.R. 2013. Função de resposta do meloeiro a doses de adubação nitrogenada para dois níveis de irrigação. Comunicata Scientiae 4: 391-400.

Soares, J.M., Costa, F.F. 2000. Irrigação na cultura da videira. Informe Agropecuário 19: 58-69.

Souza, E.R, Pionório, J.A.A., Ribeiro, V.G., Queiroz, S.O.P. 2013. Produção de videira 'Superior Seedless' cultivadas em diferentes tensões de água no solo. Irriga 18: 232-242.

Souza, E.R., Ribeiro, V.G., Pionório, J.A.A. 2011. Percentagem de fertilidade gemas e teores carboidratos em raízes, sarmentos e folhas da videira cultivar Itália. Revista Brasileira de Tecnologia Aplicada nas Ciências Agrárias 4: 83-95. 